\title{
Antinutrients, In Vitro Digestibility and Antioxidant Activity of Sorghum Grain and Flour of Two Different Varieties
}

\author{
Sarita Verma ${ }^{1}$, Neelam Khetrapaul ${ }^{2}$, Sarita Verma ${ }^{1}$ and Vandana Verma ${ }^{3 *}$ \\ ${ }^{1}$ (Foods \& Nutrition), ${ }^{2}$ (DEE), ${ }^{3}$ (EECM) I. C. College of Home Science, CCS Haryana \\ Agricultural University, Hisar - 125004, Haryana, India \\ *Corresponding author
}

\begin{tabular}{|l|}
\hline Ke y w o r d s \\
$\begin{array}{l}\text { Antinutrients, In } \\
\text { vitro digestibility } \\
\text { and Antioxidant } \\
\text { activity }\end{array}$ \\
\hline Article Info \\
\hline $\begin{array}{l}\text { Accepted: } \\
\text { 20 April } 2018 \\
\text { Available Online: } \\
\text { 10 May 2018 }\end{array}$ \\
\hline
\end{tabular}

\section{Introduction}

Sorghum is the fifth most important cereal crop in the world after rice, wheat, corn and barley. It is the main cereal food for over 750 million people living in semi-arid tropical regions of Africa, Asia and Latin America.
Sorghum commonly is eaten with the hull (the outer layer of the grain), which retains the majority of the nutrients. Sorghum has excellent chemical and physical properties, which make it a grain of good quality for processing different types of products. The nutrient composition of sorghum grain indicates that it is a good source of carbohydrates, fibre, protein, vitamins and minerals. Sorghum contains about 70 per cent starch, so is a good energy source. Its starch consists of 70 to 80 per cent amylopectin, a branched-chain polymer of glucose, and 20 to 30 per cent amylase, a straight-chain polymer. In-vitro protein digestibility of wheat (control), HC-308 and HJ-513 was 71.12, 69.66 and 69.86 per cent, respectively which did not vary among them. In-vitro starch digestibility of wheat (control), HC-308 and HJ-513 i.e. 32.98, 31.46 and 32.39 (mg maltose released/g meal) was found, which too did not vary. Phytic acid content of HC $308(565.6 \mathrm{mg} / 100 \mathrm{~g})$ and HJ-513 (587.6 mg/100g) did not differ but both had significantly higher $(\mathrm{p} \leq 0.05)$ phytic acid content when compared to that of wheat (control) $(469.3 \mathrm{mg} / 100 \mathrm{~g})$. Polyphenol content of HC-308 $(757.95 \mathrm{mg} / 100 \mathrm{~g})$ and HJ-513 (752.95mg/100g) did not vary. However, both sorghum varieties had higher polyphenol contents when compared to that of wheat (control) i.e $466.33 \mathrm{mg} / 100 \mathrm{~g}$. Total phenolic contents of two sorghum varieties viz. HC308 and HJ-513 and wheat (control) varied i.e. 7.03, 7.13 and $5.26 \mathrm{mg} \mathrm{GAE} / \mathrm{g}$, respectively. DPPH free radical scavenging activity of HC 308 and HJ-513 had antioxidant activity of 50.10 and 52.55 per cent, respectively which were higher than antioxidant activity of wheat control $(42.58 \%)$. 
In Sorghum, the cultivation area is showing a decreasing trend and the reduction is to the extent of 41.81 per cent from the year 2008-09 to $2014-15$ and a decline 74.71 per cent was recorded over the past four decades in the country. The crop is primarily produced in Maharashtra and southern states of Karnataka and Andhra Pradesh. These, three states together account for close to 80 per cent of the all-India production. Madhya Pradesh, Gujarat and Rajasthan are the other states producing sorghum. In many semi-arid countries of Africa and Asia, grains occupy an important place in the food and feed. It is one of the major cereal crops produced and consumed after rice (Oryza sativa) and wheat (Triticum aestivum). Sorghum grains are used by these people (especially farmers), who often do not have the means to feed themselves with food sources of energy, rich in protein, vitamins, minerals. Sorghum grains are rich in energy and non-energy nutrients (Ramatoulaye et al., 2016). Sorghum commonly is eaten with the hull (the outer layer of the grain), which retains the majority of the nutrients. Sorghum has excellent chemical and physical properties, which make it a grain of good quality for processing different types of products. The nutrient composition of sorghum grain indicates that it is a good source of carbohydrates, fibre, protein, vitamins and minerals. Sorghum contains about 70 per cent starch, so is a good energy source. Its starch consists of 70 to 80 per cent amylopectin, a branched-chain polymer of glucose, and 20 to 30 per cent amylose, a straight-chain polymer.

It is a gluten-free, high protein and cholesterol-free source of a variety of essential nutrients i.e. iron, zinc, manganese and copper. Sorghum has the potential for high levels of iron (more than $70 \mathrm{ppm}$ ) and zinc (more than $50 \mathrm{ppm}$ ) in the grain. It is rich in B-complex vitamins like thiamine, riboflavin, niacin, pantothenate, and vitamin $\mathrm{B}_{6}$ which play key role in energy metabolism. Sorghum's high-energy content and ready supply of B-complex vitamins are a perfect combination for energy utilization.

Depending upon the variety, sorghum provides good to excellent sources of phytochemicals such as phenolic acids, anthocyanins, phytosterols and policosanols etc. and antioxidants which are believed to help lower the risk of cancer, diabetes, heart disease and some neurological diseases. The wax surrounding the sorghum grain contains compounds, policosanols that may have an impact on human cardiac health.

As with other foodstuffs, certain nutritional inhibitors and toxic substances are associated with sorghum grains as well which lower its nutritional value. The antinutritional effect of tannin and phytate in sorghum has been demonstrated by many researchers. The tannin-protein interaction in sorghum involves hydrogen bonding and hydrophobic interactions. Sorghum prolamins (proline-rich proteins) bind strongly to sorghum tannins and these results in reduced protein digestibility (Abdelhaleem et al., 2008). Like all grain species, sorghum contains phytic acid which binds minerals and reduces their availability to the consumer. However, these antinutrients could be eliminated or reduced by processes such as soaking, dehulling, popping, germination and fermentation involved in processing of sorghum during product development (Ugwu and Oranye, 2006). During the value addition and application of suitable processing methods, the utilization of sorghum, being a cheap protein and mineral source, can be greatly enhanced. As per the 2012 report of the statistical appraisal on children in India, the prominent findings relevant to nutritional status is described as 48 percent of children under age five years are stunted which indicates that, half of the country's children are chronically 
malnourished. Acute malnutrition, as evidenced by wasting which results in a child being too thin for his or her height. Approximately 20 percent of children less than five years in the country are wasted which indicates that, one out of every five children in India is wasted. Nearly 45 percent of children under five years of age are underweight. Prevalence of stunting and underweight was highest in age group 11 to 13 years, whereas prevalence of wasting was highest in age group of 5 to 7 years. With the revelation of the above findings, it is reassured that malnutrition is not the result of a single cause; the problem is multifaceted, the causes acting singly or in combination with other complex factors like poverty, purchasing power, health care, ignorance on nutrition and health education, female illiteracy, social convention etc. Cereal grains form a major source of dietary nutrients for all people, particularly those in the developing countries. The present study was planned with the following specific objective

To study the anti nutrients in vitro protein digestibility, starch digestibility and antioxidant activity two varieties of sorghum

\section{Materials and Methods}

\section{Procurement of raw material}

The locally available varieties of sorghum i.e HC 308 and HJ 513 were procured from the Department of Genetics and Plant Breeding, CCSHAU, Hisar. In vitro Digestibility

\section{In vitro protein digestibility}

In vitro protein digestibility was carried out by the modified method of Mertz et al., (1983).

\section{Reagents}

Pepsin reagent: $0.1 \quad \mathrm{M} \quad \mathrm{KH}_{2} \mathrm{PO}_{4} \quad(\mathrm{pH} \quad 2.0$ ) containing $0.2 \%$ pepsin; $13.6 \mathrm{~g}$ potassium phosphate was dissolved in 1 litre of water, $\mathrm{pH}$ of the solution was adjusted to 2.0 and $2 \mathrm{~g}$ pepsin (Sigma Chemical Company, USA.) was dissolved in the buffer.

TCA (50 \%): $50 \mathrm{~g}$ Trichloroacetic acid was dissolved in water and volume was made to $100 \mathrm{ml}$.

\section{Procedure}

$250 \mathrm{mg}$ of sample was weighed and transferred to a centrifuge tube. To it $20 \mathrm{ml}$ of pepsin reagent was added. The tube was stoppered and arranged in a shaker-incubator maintaining the water temperature at $37^{\circ} \mathrm{C}$ for $3 \mathrm{~h}$. The centrifuge tube was removed and cooled. $5 \mathrm{ml}$ of TCA (50\%) was added and the contents were centrifuged at $10,000 \mathrm{rpm}$ for $10 \mathrm{~min}$ at room temperature and filtered. Ten ml of aliquot was taken and dried in hot air oven and digested for nitrogen determination by Micro Kjeldahl method (AOAC, 2000). Digested protein of sample was determined. Protein digestibility was calculated by the following formula:

Digested protein

$\begin{aligned} \text { Protein digestibility }(\%)= & --------------\times 100 \\ & \text { Total protein }\end{aligned}$

\section{In vitro starch digestibility}

In vitro starch digestibility was assessed by employing method of Singh et al., 1982.

\section{Reagents}

Pancreatic amylase: Twenty mg pancreatic amylase (Sigma Chemical Company, USA) was dissolved in $50 \mathrm{ml}$ phosphate buffer $(\mathrm{pH}$ 6.9 ).

0.2 M Disodium hydrogen phosphate: Dissolved $35.598 \mathrm{~g}$ disodium hydrogen phosphate in distilled water and volume was made to one litre. 
Concentration from graph (mg)

0.2 M Potassium dihydrogen phosphate: Dissolved $27.28 \mathrm{~g}$ potassium dihydrogen phosphate in distilled water and volume was made to one litre.

Phosphate buffer (pH 6.9): Added $50 \mathrm{ml} 0.2$ M Potassium dihydrogen phosphate to $46.8 \mathrm{ml}$ $0.2 \mathrm{M}$ sodium hydrogen phosphate and volume was made upto $200 \mathrm{ml}$.

Di -nitrosalicylic reagent: 3,5-dinitrosalicylic acid $(10 \mathrm{~g})$, sodium potassium tartarate $(300 \mathrm{~g})$ and sodium hydroxide (16 g) were dissolved in carbon dioxide free water and volume was made to 1 litre. The reagent was stored in brown bottle and protected from carbon dioxide.

Standard maltose solution: Maltose monohydrate $(100 \mathrm{mg})$ was dissolved in distilled water and volume was made up to $100 \mathrm{ml}$.

\section{Estimation}

Fifty $\mathrm{mg}$ defatted sample was dispersed in 1.0 $\mathrm{ml} 0.2 \mathrm{M}$ phosphate buffer ( $\mathrm{pH}$ 6.9). $0.5 \mathrm{ml}$ pancreatic amylase was added and incubated in water bath at $37^{\circ} \mathrm{C}$ for $2 \mathrm{~h}$ with occasional shaking of the test tubes. After incubation, 2 $\mathrm{ml}$ dinitrosalicylic reagent was quickly added and heated for $5 \mathrm{~min}$ in a boiling water bath. After cooling, the solution was made to $25 \mathrm{ml}$ with distilled water and filtered through an ordinary filter paper prior to measurement of absorbance at $550 \mathrm{~nm}$. A blank was run simultaneously by incubating the sample without enzyme. Dinitrosalicylic reagent was added before addition of the enzyme solution. Values were expressed as $\mathrm{mg}$ maltose released/g defatted sample. Standard curve was prepared by taking 0.5 to $4.0 \mathrm{mg}$ maltose from standard maltose solution. The starch digestibility was calculated as:
In vitro starch digestibility $=$

Weight of sample (g)

\section{Anti-nutritional factors}

\section{Phytic acid}

Phytic acid content was determined by the method of Davies and Reid (1979).

\section{Reagents}

Nitric acid (0.5M): $\mathrm{HNO}_{3} 69.5 \%(15.96 \mathrm{ml})$ (AR grade, sp. gr.1.42) was diluted to $500 \mathrm{ml}$ with distilled water.

Ferric ammonium sulphate: Ferric ammonium sulphate $(215 \mathrm{mg})$ was dissolved in distilled water. To it few drops of $\mathrm{HCl}$ were added and volume was made to $500 \mathrm{ml}$ with distilled water.

Ammonium thiocyanate: Ammonium thiocyanate $(10 \mathrm{~g})$ was dissolved in distilled water and volume was made to $100 \mathrm{ml}$.

Iso-amyl alcohol Sodium phytate: Sodium phytate $\left(\begin{array}{llllll}5.5 & \% & \mathrm{H}_{2} \mathrm{O}, & 97 & \% & \text { purity and }\end{array}\right.$ containing $12 \mathrm{Na} /$ mole) was dissolved in 100 $\mathrm{ml}$ of $0.5 \mathrm{M} \mathrm{HNO}_{3}$, which gave a solution containing $20 \mathrm{mg}$ phytic acid in $100 \mathrm{ml}$ or 200 $\mu \mathrm{g}$ phytic acid $/ \mathrm{ml}$.

\section{Extraction}

To $500 \mathrm{mg}$ sample, $20 \mathrm{ml} 0.5 \mathrm{M} \mathrm{HNO}_{3}$ was added in a conical flask and shaken continuously for $3 \mathrm{~h}$ on shaker at room temperature. The contents were centrifuged at $800 \mathrm{rpm}$ for $15 \mathrm{~min}$. Supernatant was used for estimation of phytic acid.

\section{Procedure}

To a test tube, $0.5 \mathrm{ml} \mathrm{HNO}_{3}$ extract was taken and volume was made to $1.4 \mathrm{ml}$ with water. 
To it, $1 \mathrm{ml}$ ferric ammonium sulphate solution wad added, the contents were thoroughly mixed and placed in boiling water bath for 20 min. immediately the tubes were cooled to room temperature under tap water.

Five ml iso-amyl alcohol was added to it, the contents were mixed vigorously and to it, 0.1 $\mathrm{ml}$ ammonium thiocyanate solution was added. The tubes were shaken well and centrifuged at $300 \mathrm{rpm}$ for $10 \mathrm{~min}$. Colour intensity in the alcohol was read exactly after 15 min of addition of ammonium thiocyanate at $465 \mathrm{~nm}$ against iso-amyl alcohol blank. For plotting a standard curve, 0.2 to $1.2 \mathrm{ml}$ standard phytate solution containing 40- 240 $\mu \mathrm{g}$ phytic acid was taken and made to $1.4 \mathrm{ml}$ with water.

The phytic acid was calculated by the formula:

Phytic acid $(\mathrm{mg} / 100 \mathrm{~g})=\frac{\mathrm{M} \times \mathrm{V} \times 100}{\mathrm{~W} \times \mathrm{V} 1 \times 1000}$

Where,

$\mathrm{M}=$ concentration of sample for graph

$\mathrm{W}=$ weight of sample

$\mathrm{V}=$ volume of extract made

$\mathrm{V} 1$ = volume of aliquot taken

\section{Polyphenols}

Total polyphenols were extracted by the method of Singh and Jambunathan (1981). Defatted sample (500 mg) was refluxed with $50 \mathrm{ml}$ methanol containing one per cent $\mathrm{HCl}$ for $4 \mathrm{~h}$. The extract was concentrated by evaporating on a hot water bath and brought its volume to $25 \mathrm{ml}$ with methanolic - $\mathrm{HCl}$. The amount of polyphenolic compounds was estimated as tannic acid equivalent according to Folin-Danis procedure (Swain and Hills, 1959).

\section{Reagents}

Folin-Denis reagent: To $750 \mathrm{ml}$ water, $100 \mathrm{~g}$ sodium tungstate, $20 \mathrm{~g}$ phosphomolybdic acid and $50 \mathrm{ml}$ phosphoric acid were added and heated and then refluxed for $2 \mathrm{~h}$. It was cooled and diluted to one litre.

Tannic acid (stock solution): $100 \mathrm{mg}$ of tannic acid was dissolved in water and made upto one litre. In order to have working standard solution, $20 \mathrm{ml}$ stock solution was further diluted to $100 \mathrm{ml}$ with water.

Saturated aqueous sodium carbonate solution: Dissolved $350 \mathrm{~g}$ sodium carbonate in one litre hot distilled water at $70^{\circ} \mathrm{C}$ to $80^{\circ} \mathrm{C}$, cooled and filtered through glass wool.

\section{Procedure}

Test solution $(1.5 \mathrm{ml})$ was diluted with distilled water to $8.5 \mathrm{ml}$ in a graduated test tube. After thorough mixing, added $0.5 \mathrm{ml}$ Folin- Denis reagent and the tubes were well shaken. Exactly after 3 minutes, one $\mathrm{ml}$ of saturated sodium carbonate solution was added and the tubes were thoroughly shaken again. After an hour, the absorbance was read at $725 \mathrm{~nm}$ on UV- VIS Spectrophotometer118 using a suitable blank. If the solution was cloudy or precipitates appeared, it was centrifuged before readings were taken. A standard curve was plotted by taking $0.5 \mathrm{ml}$ to $4.0 \mathrm{ml}$ working tannic standard solution containing $10 \mu \mathrm{g}$ to $80 \mu \mathrm{g}$ tannic acid.

Polyphenols $(\mathrm{mg} / 100 \mathrm{~g})=\frac{\mathrm{M} \times \mathrm{V} \times 100}{\mathrm{~W} \times \mathrm{-} \times--------}$

Where,

$\mathrm{M}=$ Concentration of extract elute obtained from graph

$\mathrm{V}=$ Volume made of extract $(\mathrm{ml})$ 
$\mathrm{W}=$ Weight $(\mathrm{g})$ of the sample

$\mathrm{V} 1=$ Volume of extract aliquot taken $(\mathrm{ml})$

\section{Antioxidant activity}

\section{Total phenolic content}

Total phenolic contents were estimated by the method of Singleton and Rossi (1965).

\section{Reagents}

\section{Folin-Ciocalteu reagent $(1 \mathrm{~N})$}

Sodium carbonate $\left(\mathrm{Na}_{2} \mathrm{CO}_{3}\right)$ : Dissolved $200 \mathrm{~g}$ anhydrous sodium carbonate in $800 \mathrm{ml}$ water and brought to a boil. After cooling, added a few crystals of sodium carbonate and let it sit for $24 \mathrm{~h}$ at room temperature. Filtered through Whatman \# 1 filter paper and added water to make the volume to 1 liter.

Standard gallic acid

\section{Preparation of calibration curve using gallic acid as standard}

Ten mg of standard gallic acid was accurately weighed and dissolved in $100 \mathrm{ml}$ distilled water in a volumetric flask $(100 \mu \mathrm{g} / \mathrm{ml}$ of stock solution). From the above stock solution, 0.1 to $1 \mathrm{ml}$ aliquots were pipetted out into 25 $\mathrm{ml}$ volumetric flask. Ten $\mathrm{ml}$ of distilled water and $1.5 \mathrm{ml}$ of Folin-Ciocalteu reagent were added and diluted accordingly to the label specification to each of the above volumetric flasks. After $5 \mathrm{~min} ., 4 \mathrm{ml}$ of 20 percent sodium carbonate solution was added and volume was made upto $25 \mathrm{ml}$ with distilled water. Absorbance was recorded after $30 \mathrm{~min}$. at 765 $\mathrm{nm}$ and calibration curve of absorbance verses concentration was plotted.

Table.1 Phytic acid (mg/100g) and polyphenol contents (mg/100g) of sorghum varieties (on dry matter basis)

\begin{tabular}{|c|c|c|c|c|c|}
\hline \multicolumn{2}{|l|}{ Parameters } & \multicolumn{2}{|c|}{ Sorghum varieties } & \multirow{2}{*}{$\begin{array}{l}\text { Wheat } \\
\text { (control) }\end{array}$} & \multirow[t]{2}{*}{$\mathrm{CD}(\mathrm{p} \leq 0.05)$} \\
\hline & & HC 308 & HJ 513 & & \\
\hline \multirow{2}{*}{$\begin{array}{l}\text { Antinutrient } \\
\text { content }\end{array}$} & Phytic acid & $565.6 \pm 8.59^{\mathrm{a}}$ & $587.6 \pm 11.62^{\mathrm{a}}$ & $469.3 \pm 5.24^{\mathrm{a}}$ & 42.54 \\
\hline & Polyphenol & $757.95 \pm 35.30^{\mathrm{a}}$ & $752.95 \pm 35.53^{\mathrm{a}}$ & $466.33 \pm 2.40^{\mathrm{a}}$ & 79.05 \\
\hline
\end{tabular}

Values are mean $\pm \mathrm{SE}$ of three independent determinations

Similar superscripts in the column indicate that they do not differ significantly $(\mathrm{p} \leq 0.05)$

Table.2 In vitro protein (\%) and starch (mg maltose released/g meal) digestibility of sorghum varieties (on dry matter basis)

\begin{tabular}{|c|c|c|c|c|c|}
\hline \multicolumn{2}{|c|}{ Parameters } & \multicolumn{2}{|c|}{ Sorghum varieties } & \multirow{2}{*}{$\begin{array}{l}\text { Wheat } \\
\text { (control) }\end{array}$} & \multirow[t]{2}{*}{$C D(p \leq 0.05)$} \\
\hline & & HC 308 & HJ 513 & & \\
\hline \multirow[b]{2}{*}{ IVD } & Protein & $69.66 \pm 1.40^{\mathrm{a}}$ & $69.86 \pm 2.21^{\mathrm{a}}$ & $71.12 \pm 0.15^{\mathrm{a}}$ & NS* \\
\hline & Starch & $31.46 \pm 0.29^{\mathrm{a}}$ & $32.39 \pm 0.22^{\mathrm{a}}$ & $32.98 \pm 0.22^{\mathrm{a}}$ & NS* \\
\hline
\end{tabular}

Values are mean $\pm \mathrm{SE}$ of three independent determinations

Similar superscripts in the column indicate that they do not differ significantly $(\mathrm{p} \leq 0.05)$

*Not significant

Table.3 Total phenolic contents (mg GAE/g) and DPPH free radical scavenging activity (\%) of sorghum varieties (on dry matter basis) 


\begin{tabular}{|c|c|c|c|c|}
\hline \multirow[t]{2}{*}{ Antioxidant activity } & \multicolumn{2}{|c|}{ Sorghum varieties } & \multirow{2}{*}{$\begin{array}{l}\text { Wheat } \\
\text { (Control) }\end{array}$} & \multirow[t]{2}{*}{$C D(p \leq 0.05)$} \\
\hline & HC 308 & HJ 513 & & \\
\hline $\begin{array}{l}\text { Total phenolic content } \\
\text { (mg GAE/g) }\end{array}$ & $7.03 \pm 0.01^{\mathrm{a}}$ & $7.13 \pm 0.02^{\mathrm{a}}$ & $5.26 \pm 0.18^{b}$ & 0.40 \\
\hline $\begin{array}{l}\text { DPPH free radical } \\
\text { scavenging activity }(\%)\end{array}$ & $50.10 \pm 2.97^{\mathrm{a}}$ & $52.55 \pm 1.52^{\mathrm{a}}$ & $42.58 \pm 0.69^{b}$ & 7.48 \\
\hline
\end{tabular}

Values are mean \pm SE of three independent determinations

Similar superscripts in the column indicate that they do not differ significantly $(\mathrm{p} \leq 0.05)$

Fig.1 Phytic acid (mg/100g) and polyphenol contents $(\mathrm{mg} / 100 \mathrm{~g})$ of sorghum varieties (on dry matter basis)

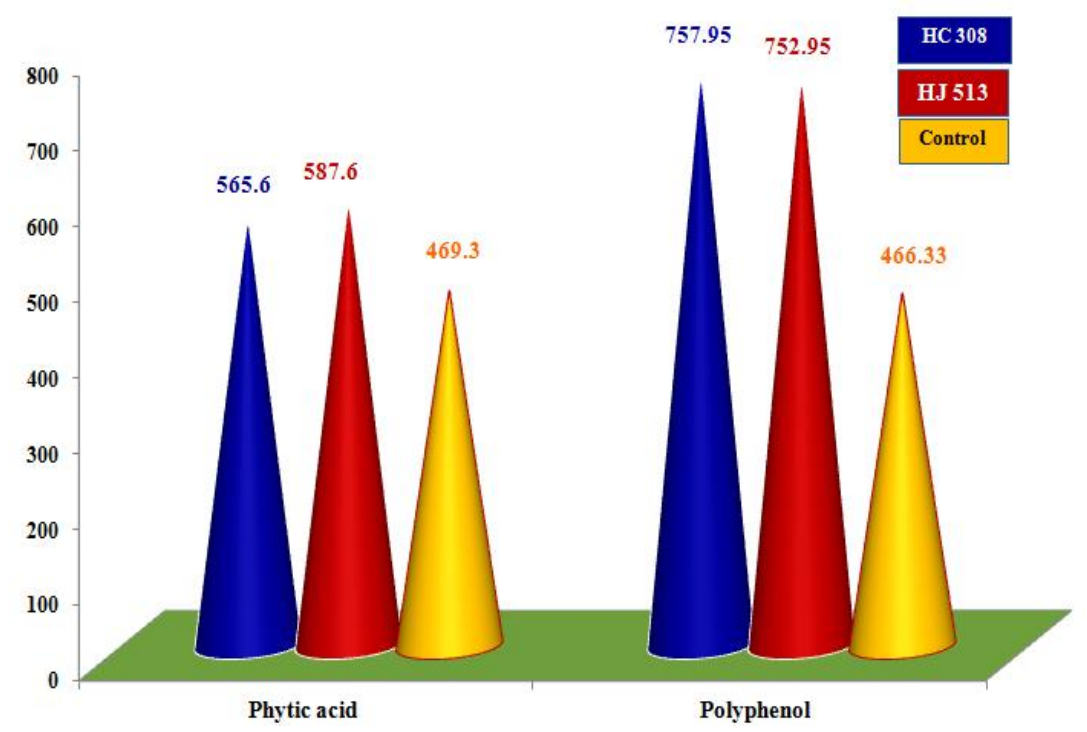

\section{Procedure}

One $\mathrm{g}$ of sample was added to $15 \mathrm{ml}$ of methanol $(50 \%)$ and extracted for three times by maceration of 2 hours. Then it was filtered and volume was made 50 volumetric flask with methanol $(50 \%)$. One $\mathrm{ml}$ aliquot of the sample was taken in a test tube and diluted with $10 \mathrm{ml}$ of distilled water.

Then, $1.5 \mathrm{ml}$ Folin-Ciocalteu reagent was added and allowed to incubate at room temperature for $5 \mathrm{~min}$, then $4 \mathrm{ml}$ of $20 \%$ (w.v) $\mathrm{Na}_{2} \mathrm{CO}_{3}$ was added, adjusted with distilled water up to the mark $25 \mathrm{ml}$, agitated and left to stand for $30 \mathrm{~min}$ at room temperature. Absorbance of sample was measured at $765 \mathrm{~nm}$. Quantification was done on the basis of a standard curve of gallic acid. Results were expressed as $\mu \mathrm{g}$ gallic acid equivalent (GAE) and percentage w/w.

\section{(DPPH) 2, 2'- Diphenyl-1-picrylhydrazyl free radical scavenging activity (RSA)}

The DPPH free radical scavenging activity of sample extracts was evaluated by the DPPH method of Hatano et al., (1988).

\section{Reagents}

DPPH: $2.5 \mathrm{mg} / 1$ in methanol

\section{Procedure}

DPPH is a stable free radical that shows a maximum absorption at $517 \mathrm{~nm}$. When DPPH 
encounters proton donating substance such as antioxidant and a radical species, the absorbance at $517 \mathrm{~nm}$ disappears because the DPPH radical is scavenged. On the basis of this principle, the radical scavenging effect of each fraction was measured. For this, in 0.2 $\mathrm{ml}$ of methanol extract, $3.0 \mathrm{ml}$ of DPPH was added and mixed thoroughly for $5 \mathrm{~min}$.

A control was also made containing $0.2 \mathrm{ml}$ of solvent (methanol) instead of extract (at zero min). The absorbance of the sample as well as control was measured at $517 \mathrm{~nm}$ after $30 \mathrm{~min}$. of incubation in dark at room temperature using the UV-VIS double beam Spectrophotometer Model 2203 against a blank containing respective solvent. Three replications were carried out for each sample. The percent of DPPH radical discoloration of the sample was calculated according to the equation (\%) discoloration:

DPPH free radical scavenging activity $(\%)=$ $\mathrm{A}_{\text {control }}-\mathrm{A}_{\text {sample }} \times 100 / \mathrm{A}_{\text {control }}$

Where,

$\left(\mathrm{A}_{\text {control }}\right)=$ absorbance for the control $\left(\mathrm{A}_{\text {sample }}\right)=$ absorbance for the sample

\section{Results and Discussion}

\section{Antinutrients}

Data pertaining to antinutrients content of sorghum varieties is presented in Table 1 , Phytic acid contents of HC 308 (565.6 $\mathrm{mg} / 100 \mathrm{gm})$ and HJ 513(587.6 mg/100g) did not differ significantly $(\mathrm{p} \leq 0.05)$ but both had significantly higher phytic acid content when compared to that of wheat (control) 469.3 mg/100 g (Fig. 1).

Polyphenol content of HC 308 (757.95mg/100g) and HJ 513(752.95mg/ $100 \mathrm{~g}$ ) followed the same trend and did not vary significantly $(\mathrm{p} \leq 0.05)$. However, both had higher polyphenol content when compared to that of wheat (control) 466.33 $\mathrm{mg} / 100 \mathrm{~g}$.

\section{In vitro digestibility}

Data pertaining to in vitro digestibility in sorghum varieties is presented in Table 2 . invitro protein digestibility of wheat control cereal bar, HC 308 and HJ 513 was found to be $71.12,69.66$ and 69.86 per cent, respectively which did not vary significantly $(\mathrm{p} \leq 0.05)$ among themselves. Similar trend was noticed for in vitro starch digestibility of wheat (control), HC 308 and HJ 513 which too did not vary significantly $(\mathrm{p} \leq 0.05)$ among themselves and ranged from 31.46 to $32.98 \mathrm{mg}$ maltose released per $\mathrm{g}$.

\section{Antioxidant activity}

The data related to antioxidant activity is given in Table 3. Total phenolic contents of two varieties viz. HC 308 and HJ 513 were found to be similar. However, wheat (control) depicted significantly $(\mathrm{p} \leq 0.05)$ lower $5.26 \mathrm{mg}$ GAE/g of total phenolic content in comparison to that of HC 308 and HJ 513.

HC 308 and HJ 513 had DPPH free radical scavenging activity of 50.10 and 52.55 per cent, respectively which did not vary significantly. However, both the varieties had significantly $(\mathrm{p} \leq 0.05)$ higher $\mathrm{DPPH}$ free radical scavenging activity in comparison to that of wheat (control) 42.58 percent.

In-vitro protein digestibility of wheat (control), HC-308 and HJ-513 was 71.12, 69.66 and 69.86 per cent, respectively which did not vary among themselves. In-vitro starch digestibility of wheat (control), HC308 and HJ-513 i.e. $32.98,31.46$ and 32.39 (mg maltose released/g meal) was found, which too did not vary. Phytic acid content of HC 308 (565.6 mg/100 g) and HJ-513 (587.6 
$\mathrm{mg} / 100 \mathrm{~g}$ ) did not differ but both had significantly higher $(\mathrm{p} \leq 0.05)$ phytic acid content when compared to that of wheat (control) (469.3 mg/100 g). Polyphenol content of HC-308 (757.95mg/100g) and HJ$513(752.95 \mathrm{mg} / 100 \mathrm{~g})$ did not vary. However, both sorghum varieties had higher polyphenol contents when compared to that of wheat (control) i.e., $466.33 \mathrm{mg} / 100 \mathrm{~g}$. Total phenolic contents of two sorghum varieties viz. HC308 and HJ-513 and wheat (control) varied i.e. $7.03,7.13$ and $5.26 \mathrm{mg} \mathrm{GAE} / \mathrm{g}$, respectively. DPPH free radical scavenging activity of HC 308 and HJ-513 had antioxidant activity of 50.10 and 52.55 per cent, respectively which were higher than antioxidant activity of wheat control $(42.58 \%)$.

\section{References}

Awadelkareem, A. M., Muralikrishna, G., Tinay, A. H. and Mustafa, A. I. 2009. Characterization of tannin and study of in vitro protein digestibility and mineral profile of Sudanese and Indian Sorghum cultivars. Journal of Nutrition; 8(4): 469-476.

Ramatoulaye, F. M. C., Fallou, S., Amadou, K., Cyril, D. 2016. Production and Use Sorghum: A Literature Review. Journal of Nutrition Health Food Science; 4(1): 1-4.

Ugwu, F. M. and Oranye, N. A. 2006. Effects of some processing methods on the toxic components of African breadfruit (Treculia africana). African Journal of Biotechnology; 5 (22): 2329-2333.

Varsha. 2003. Nutritional evaluation of utilization of selected cereals and pulses for value addition of wheat based products. M.Sc. Thesis, CCS Haryana Agricultural University, Hisar, India.

Yadav, L. and Bhatnagar, V. 2016. Formulation, quality evaluation and shelf-life of value added cereal bar by incorporation of Defatted Soy Flour. International Journal of Food Fermentation Technology. 6(2): 251259.

\section{How to cite this article:}

Sarita Verma, Neelam Khetrapaul, Sarita Verma and Vandana Verma. 2018. Antinutrients, In Vitro Digestibility and Antioxidant Activity of Sorghum Grain and Flour of Two Different Varieties. Int.J.Curr.Microbiol.App.Sci. 7(05): 2935-2943.

doi: https://doi.org/10.20546/ijcmas.2018.705.342 